\title{
ANALISA YURIDIS PUTUSAN PERKARA NOMOR 04/PDT.G/2007/PN.PSB TENTANG PERBUATAN MELAWAN HUKUM YANG DILAKUKAN OLEH POLRI
}

\author{
Nur Salasatul Mu'asromin dan Saivol Virdaus \\ Fakultas Hukum Universitas Islam Kadiri \\ saivol@uniska-kediri.ac.id
}

\begin{abstract}
ABSTRAK
Pemberitaan tentang polisi yang melakukan penembakan sering menjadi perhatian publik, terlebih terhadap polisi yang salah tembak. Tidak sedikit polisi yang kemudian diperiksa, ditindak dan diajukan ke sidang pengadilan atau kode etik profesi karena dinilai salah tembak, atau melanggar HAM. Setiap melakukan tindakan, aparat kepolisisan mempunyai kewenangan bertindak menurut penilaiannya sendiri, dengan maksud suatu tindakan yang dapat dilakukan oleh anggota polri yang dalam bentuk bertindak harus mempertimbangkan manfaat serta resiko dari tindakannya dan betul-betul untuk kepentingan umum. Kewenangan ini tertulis dalam Pasal 18 ayat (1) Undang-Undang No. 2 Tahun 2002 tentang Kepolisian Negara Republik Indonesia yang menyatakan bahwa, "Untuk kepentingan umum, pejabat Kepolisian Negara Republik Indonesia dalam melaksanakan tugas dan wewenangnya dapat bertindak menurut penilaiannya sendiri”. Hal inilah yang terkadang disalahgunakan oleh aparat Kepolisian, sehingga lalai dalam menjalankan tugasnya. Utamanya pada kasus Putusan No. 04/PDT.G/2007/PN/PSB yang sedang di analisis dan di kaji oleh penulis saat ini. Adapun rumusan dalam penelitian ini, yaitu apa alasan atau dasar penggugat dalam mengajukan gugatan terhadap Polri dalam perkara No. 04/PDT.G/2007/PN. PSB serta bagaimana analisa mengenai pertimbangan dalam memutus perkara No. 04/PDT.G/2007/PN. PSB tentang perbuatan melawan hukum yang dilakukan oleh Polri. Adapun tujuan peneltian ini, yaitu untuk mengetahui alasan atau dasar penggugat dalam mengajukan gugatan terhadap Polri dalam perkara No. 04/PDT.G/2007/PN. PSB serta untuk mengetahui dasar pertimbangan dalam memutus perkara No. 04/PDT.G/2007/PN. PSB tentang perbuatan melawan hukum yang dilakukan oleh Polri. Dalam penelitian kali ini penulis menggunakan metode yuridis normatif yaitu mengkaji dan menganalisa Putusan Perkara Nomor 04/PDT.G/2007/PN.PSB dengan menggunakan jenis pendekatan Undang-Undang, pendekatan undang-undang dilakukan dengan menelaah semua Undang-Undang dan regulasi yang bersangkut paut dengan isu hukum yang sedang ditangani dan pendekatan kasus, melakukan telaah terhadap kasuskasus yang berkaitan dengan isu yangdihadapi yang tewlah menjadi putusan pengadilan yang telah mempunyai kekuatan hukum tetap, yang menjadi kajian pokok didalam pendekatan kasus yaitu ratio decidendi atau resasoning yaitu pertimbangan pengadilan untuk sampai kepada suatu putusan.
\end{abstract}

Kata Kunci : Kewenangan, Kepolisian, Penembakan 


\section{Pendahuluan}

Kepolisian Negara Republik Indonesia merupakan badan atau alat Negara yang bertugas memelihara kamtibmas, menegakkan hukum, melindungi, mengayomi dan melayani masyarakat. Ketiga tugas tersebut tidak dapat dipisahkan karena saling terkait satu sama lain. Kepolisian sebagai lembaga penegakan hukum dalam menjalankan tugasnya tetap tunduk dan patuh pada tugas dan wewenang sebagaimana yang diatur dalam Pasal 13 Undang-Undang Nomor 2 Tahun 2002 yang menyatakan bahwa tugas pokok Kepolisian Negara Republik Indonesia adalah : ${ }^{1}$

1.1. Memelihara keamanan dan ketertiban masyarakat

\subsection{Menegakkan hukum}

1.3. Memberikan perlindungan, pengayoman dan pelayanan kepada masyarakat.

Implementasi dari tugas polri tersebut, masyarakat mengharapkan bahwa polri mampu menghilangkan atau menanggulangi setiap permasalahan social dalam masyarakat. Sepintas harapan ini seolah-olah berlebihan karena berharap polri mampu menyelesaikan permasalahan social yang terjadi dalam masyarakat. Namun apabila ditelaah mendalam, harapan ini tidak berlebihan karena pada dasarnya setiap permasalahan sosial berpotensi berkembang menjadi gangguan keamanan dan ketertiban masyarakat yang akan mengganggu aktivitas masyarakat apabila tidak diselesaikan secara tuntas.

Harapan masyarakat yang cukup besar tersebut menunjukkan betapa masyarakat memberikan kepercayaan cukup besar kepada Polri. Masyarakat sangat mengharapkan Polri mampu mewujudkan situasi kamtibmas yang kondusif dengan memberantas segala tindak kejahatan, sehingga masyarakat merasa aman dalam menjalankan aktivitas daan kehidupannya sehari-hari. Sejalan dengan era reformasi yang di dalamnya telah di agendakan secara nasional, yaitu reformasi di bidang politik, ekonomi dan hukum, Polri juga menjadi sasaran untuk direformasi, karena reformasi merupakan reaksi

${ }^{1}$ Supriadi, Etika \& Tanggung Jawab Profesi Hukum Di Indonesia, Jakarta : Sinar Grafika, 2004, ,hlm. 134. 
masyarakat terhadap praktek penyelenggaraan Negara. Terkait reformasi Polri dibidang cultural, masyarakat belum merasakan adanya perubahan yang signifikan, sikap dan perilaku anggota kepolisian masih belum banyak berubah.

Pemberitaan tentang polisi yang melakukan penembakan sering menjadi perhatian publik, terlebih terhadap polisi yang salah tembak. Tidak sedikit polisi yang kemudian diperiksa, ditindak dan diajukan ke sidang pengadilan atau kode etik profesi karena dinilai salah tembak, atau melanggar HAM.

Secara khusus kepolisian di masing-masing Negara diharuskan untuk terus menerus meninjau kembali masalah etika yang terkait di dalam penggunaan senjata api oleh setiap organ yang memiliki otoritas untuk itu. Khususnya dalam penggunaan senjata api, harus dilihat terlebih dahulu keadaan saat polisi diperbolehkan membawa senjata api, kemudian memastikan senjata api digunakan dengan benar dan menyediakan peringatan yang harus ditembakkan.

Ketika terjadi suatu penyalahgunaan senjata api yang dilakukan oleh personil Polri, terdapat beberapa kebijakan yang diambil pimpinan Polri, mulai dari kebijakan reaktif yang memerintahkan bahwa senjata yang dipinjam pakaikan kepada semua jajaran dilapangan harus segera ditarik dan disimpan. Kemudian dilanjutkan dengan pemeriksaan terhadap kelengkapan administrasi semisal masa berlaku surat tanda ijin senjata, penelitian ulang terhadap kesehatan mental termasuk adanya pemeriksaan atas permasalahan keluarga anggota yang bersangkutan. Selain kebijakan reaktif yang dilakukan pasca terjadi penyalahgunaan senjata api, terdapat alternatif kebijakan yang dapat diterapkan antara lain adalah kebijakan proaktif pencegahan dan upaya preventif penyalahgunaan senjata api.

Polri sebagai institusi Negara yang paling depan dalam menjalankan fungsi dan tugas yang di embannya selalu bersinggungan langsung dengan masyarakat, sehingga ada hal yang wajar dan dapat dipahami apabila Polri lah yang dapat memperoleh kritikan dari masyarakat, mulai dari yang paling sopan sampai dengan kritikan tajam yang mengarah pada turunnya wibawa 
Polri berupa tindakan pelecehan dan dalam bentuk lainnya. Situasi seperti ini mau tidak mau akan menyulitkan pelaksanaan tugas Polri sebagai aparat Negara penegak hukum, pelindung pengayom dan pelayan masyarakat, dengan tidak menyampingkan faktor-faktor yang juga berpengaruh pada penegakan hukum. Dalam sebuah masyarakat yang otoriter fungsi kepolisian adalah melayani atasan atau penguasa untuk menjaga kemantapan kekuasaan otoriter pemerintah yang berkuasa. Jika tidak, maka polisi tidak akan memperoleh tempat dalam masyarakat Indonesia sebagai pranata otonom yang dibutuhkan keberadaannya oleh masyarakat Indonesia.

Setiap melakukan tindakan, aparat kepolisisan mempunyai kewenangan bertindak menurut penilaiannya sendiri, dengan maksud suatu tindakan yang dapat dilakukan oleh anggota polri yang dalam bentuk bertindak harus mempertimbangkan manfaat serta resiko dari tindakannya dan betul-betul untuk kepentingan umum.

Kewenangan ini tertulis dalam Pasal 18 ayat (1) Undang-Undang No. 2 Tahun 2002 tentang Kepolisian Negara Republik Indonesia yang berisi :

"Untuk kepentingan umum, pejabat Kepolisian Negara Republik Indonesia dalam melaksanakan tugas dan wewenangnya dapat bertindak menurut penilaiannya sendiri". ${ }^{2}$

Hal inilah yang terkadang disalahgunakan oleh aparat Kepolisian, sehingga lalai dalam menjalankan tugasnya. Utamanya pada kasus Putusan No. 04/PDT.G/2007/PN/PSB yang sedang di analisis dan di kaji oleh penulis saat ini, dimana saat seorang anggota polisi (Briptu Nofrizal, NRP.78101128) Polsek Kinali mendapatkan surat perintah tugas untuk melakukan penyelidikan dan penyidikan atas laporan / pengaduan oleh ibu Ani (warga masyarakat Tanjung Medan Kenagarian Kinali) mengenai tindak pidana kasus pengrusakan sebuah rumah milik Edi warga Jorong Tanjung Medan Pasaman Barat yang diduga dilakukan oleh seorang bernama Sakisman (Akan) dan kawannya Iwan Mulyadi. Surat perintah tugas tersebut tidak hanya ditujukan Briptu Nofrizal saja, namun ditujukan kepada 3 orang anggota yang ke dua

\footnotetext{
${ }^{2}$ Pudi Rahardi, Hukum Kepolisian, Surabaya : Laksbang Mediatama, 2008, hlm..98
} 
diantaranya ialah Brigadir Suardi selaku Kanit Res Kinali dengan Briptu Jimny (bagian dari surat perintah). Berbekal Surat Perintah Tugas (SPT) Polisi No. Pol SPDIK/01/I/2006/Reskrim tanggal 20 Januari 2006 sekitar pukul 12.00 WIB tersangka (Briptu Nofrizal) bertindak gegabah secara sendiri tanpa berkoordinasi dengan kedua anggota polisi (Brigadir Suardi dan Briptu Jimmy) yang juga di tugaskan dalam Surat Perintah Tugas (SPT) tersebut untuk melakukan penyelidikan terhadap laporan tersebut. Sesampainya di sebuah pondok (gubug) di sawah, tersangka (Briptu Nofrizal melihat Sakisman (Akan) di luar (dibawah) pondok sedangkan korban (Iwan) berada di dalam (diatas) pondok dan menanyakan keberadaan Iwan Mulyadi kepada Sakisman, kemudian Sakisman menjawab bahwa Iwan Mulyadi berada di atas, pada waktu itu juga Briptu Nofrizal berteriak dan menyuruh Iwan Mulyadi untuk turun dari pondok, jika tidak maka Briptu Nofrizal akan menembaknya (kesaksian Sakisman). Kemudian Iwan Mulyadi turun dari pondok, belum sampai dibawah tahu-tahu Briptu Nofrizal menembak Iwan Mulyadi hingga terjatuh ditanah sampai terkulai lemas. Korban terkena tembakan senjata api jenis Revolver Colt 38 Merk Taurus XK 253941 yang mengenai rusuk sebelah kiri dan / atau mengenai syaraf tulang belakang (vertebrata) sehingga menyebabkan korban tidak bisa berdiri dan berjalan alias mengalami kelumpuhan permanent / total.

Dalam kasus ini terdapat 1 (satu) penggugat (pihak Iwan Mulyadi) dan 2 (dua) tergugat, tergugat 1 (Pemerintah Republik Indonesia Cq. Presiden RI di Jakarta, Cq. Kepala Kepolisian Republik Indonesia (Kapolri di Jakarta), Cq. Kepala Kepolisian Daerah Sumatera Barat (Kapolda) di Padang, Cq. Kepala Kepolisian Resor Pasaman Barat (Kapolres Pasaman Barat) di Jln Bhineka Tunggal Ika No. 60 Simpang Empat, Cq. Kepala Kepolisian Sektor Kinali (Kapolsek Kinali) di Kecamatan Kinali Pasaman Barat, tergugat 2 (Briptu Nofrizal). Akibat kelalaian tergugat 2 tersebut dalam putusan perkara (No. 04/PDT.G/2007/PN.PSB) ada salah satu putusan yang menyatakan bahwa, tergugat 1 berkewajiban menanggung ganti rugi yang timbul dari perbuatan melawan hukum yang dilakukan oleh tergugat 2 tersebut, serta membayar 
ganti rugi immateriil kepada penggugat sebesar Rp.300.000.000 (tiga ratus juta rupiah), gugatan yang di tujukan kepada Polri ini menganut teori penggabungan perkara yang terdapat dalam Pasal 98 sampai dengan Pasal 101 KUHAP yang menyatakan bahwa, dalam perkara gugatan ganti kerugian dari yang disebabkan suatu perkara pidana seorang hakim ketua sidang dapat menggabungkan perkara sesuai dengan permintaan korban (Penggugat). ${ }^{3} \mathrm{Hal}$ inilah yang membuat penulis tertarik untuk menganalisa dan mengkaji lebih dalam dan lebih luas dalam penelitian serta penulisan karya ilmiah kali ini.

Setiap orang yang melanggar peraturan baik disengaja ataupun tidak disengaja akan dikenai sanksi hukum sesuai dengan perbuatan yang telah dilakukannya. Sanksi hukum adalah akibat yang ditimbulkan jika seseorang melanggar peraturan. Setiap orang yang melanggar peraturan atau hukum akan menerima sanksi hukum atau hukuman. Menurut Pasal 10 KUHP, hukumannya meliputi hukuman pokok dan hukuman tambahan, hukuman pokok meliputi hukuman mati, hukuman penjara, hukuman kurungan, dan hukuman denda. Sedangkan hukuman tambahan meliputi pencabutan hak-hak tertentu, penempatan dalam rumah kerja pemerintah, penyitaan barang-barang tertentu, dan publikasi (pengumuman) keputusan hakim. ${ }^{4}$

Menurut Pasal 1365 KUH Perdata yang dimaksud dengan perbuatan melanggar hukum adalah perbuatan yang melawan hukum perdata yang karena salahnya telah menimbulkan kerugian bagi orang lain, yang mengharuskan orang yang karena salahnya telah menimbulkan kerugian tersebut untuk mengganti kerugian. Mengenai pertanggungjawaban perbuatan melanggar hukum dalam undang-undang ini juga telah diatur dalam Pasal 1366 dan 1367 KUH Perdata juga menyatakan bahwa, "setiap orang bertanggungjawab tidak saja untuk kerugian yang disebabkan perbuatannya, tetapi juga untuk kerugian yang disebabkan kelalaian atau kurang hatihatinya". "setiap orang bertanggungjawab tidak saja untuk kerugian yang disebabkan perbuatannya sendiri, tetapi juga untuk kerugian yang disebabkan

\footnotetext{
${ }^{3}$ Putusan Pengadilan Negeri Pasaman Barat No. 04/PDT.G/2007/PN.PSB

${ }^{4}$ Wardaningsih, Hukum Dan Peradilan, Jakarta : CV.Pamularsih, 2009, hlm. 35
} 
perbuatan orang-orang yang menjadi tanggungannya atau disebabkan oleh barang-barang yang berada dibawah pengawasannya. Majikan-majikan dan mereka yaang mengangkaat orang-orang lain untuk mewakili urusan-urusan mereka, adalah bertanggungjawab atas kerugian yang diterbitkan oleh pelayan-pelayan atau bawahan-bawahan mereka di dalam melakukan pekerjaan untuk mana orang-orang ini dipakainnya."

\section{Rumusan Masalah}

2.1. Apa alasan atau dasar penggugat dalam mengajukan gugatan terhadap Polri dalam perkara No. 04/PDT.G/2007/PN. PSB.

2.2. Apa dasar pertimbangan hukum dalam memutus perkara No. 04/PDT.G/2007/PN. PSB tentang perbuatan melawan hukum yang dilakukan oleh Polri.

\section{Tujuan Penelitian}

3.1. Untuk menganalisa alasan atau dasar penggugat dalam mengajukan gugatan terhadap Polri dalam perkara No. 04/PDT.G/2007/PN. PSB.

3.2. Untuk menganalisa dasar pertimbangan hukum dalam memutus perkara No. 04/PDT.G/2007/PN. PSB tentang perbuatan melawan hukum yang dilakukan oleh Polri.

\section{Metode Penelitian}

\subsection{Jenis Penelitian}

Dalam penelitian ini digunakan metode yuridis normatif yang mengacu pada norma-norma hukum yang terdapat dalam peraturan perundangudangan dan putusan-putusan pengadilan serta norma-norma hukum yang ada dalam masyarakat. ${ }^{5}$

\footnotetext{
${ }^{5}$ Zainuddin Ali, Metode Penelitian Hukum, Jakarta : Sinar Grafika, 2009, hlm.105
} 


\subsection{Pendekatan Penelitian}

\subsubsection{Pendekatan Undang-Undang (Statute Approach)}

Pendekatan undang-undang dilakukan dengan menelaah semua undang-undang dan regulasi yang bersangkut paut dengan isu hukum yang sedang ditangani. ${ }^{6}$

\subsubsection{Pendekatan Kasus (Case Approach)}

Pendekatan kasus dilakukan dengan cara melakukan telaah terhadap kasus-kasus yang berkaitan dengan isu yang dihadapi yang telah menjadi putusan pengadilan yang telah mempunyai kekuatan hukum yang tetap. Kasus itu dapat berupa kasus yang terjadi di Indonesia maaupun di negara lain. Yang menjadi kajian pokok di dalam pendekatan kasus adalah ratio decidendi atau reasoning yaitu pertimbangan pengadilan untuk sampai kepada suatu putusan. ${ }^{7}$

\subsection{Data Penelitian atau Bahan Hukum}

4.3.1. Bahan Hukum Primer, merupakan bahan hukum yang bersifat autoritatif, artinya mempunyai otoritas. Bahan-bahan hukum primer terdiri dari perundang-undangan, catatan-catatan resmi atau risalah dalam pembuatan perundang-undangan dan putusanputusan hakim. ${ }^{8}$ Bahan hukum tersebut antara lain :

4.3.1.1. Putusan Perkara No.04/PDT.G/2007/PN.PSB Tahun 2008

\subsubsection{Kitab Undang-Undang Hukum Pidana (KUHP)}

4.3.1.3. Kitab Undang-Undang Hukum Perdata (KUH Perdata)

4.3.1.4. Undang-Undang No.8 Tahun 1948 tentang Senjata Api

4.3.1.5. Undang-Undang No.12 Tahun 1951 tentang Mengubah "Ordonnantietijdelijke Bijzondere Strafbepalingen" 
(STBL. 1948 NOMOR 17) Dan Undang-Undang Republik Indonesia Dahulu Nomor 8 Tahun 1948

4.3.1.6. Ordonansi Senjata Api tahun 1939 jo UU Darurat No.12 Tahun 1951

4.3.1.7. Undang-Undang No. 2 Tahun 2002 tentang Pengertian Fungsi dan Tujuan Kepolisian RI

4.3.1.8. PP No. 2 Tahun 2003 tentang Kewajiban, Larangan dan Sanksi bagi Anggota Polri

4.3.1.9. Peraturan Kapolri No. 7 Tahun 2006 tentang Kode Etik Profesi Polri

4.3.1.10. Peraturan Kapolri No. 8 Tahun 2006 tentang Organisasi dan Tata Kerja Komisi Kode Etik Polri

4.3.1.11. Peraturan Kepala Kepolisian Negara Republik Indonesia No. 1 Tahun 2009 tentang Penggunaan Kekuatan

4.3.1.12. Peraturan Kepala Kepolisian Negara Republik Indonesia No. 8 Tahun 2009 tentang prosedur tembak ditempat.

4.3.2. Bahan Hukum Sekunder, bahan-bahan sekunder berupa semua publikasi tentang hukum yang bukan merupakan dkumendokumen resmi. Publikasi tentang hukum meliputi buku-buku teks, kamus-kamus hukum, jurnal-jurnal hukum, dan komentarkomentar atas putusan pengadilan. ${ }^{9}$

4.3.3. Bahan Non Hukum, bahan-bahan nonhukum dapat berupa bukubuku memngenai ilmu politik, ekonomi, sosiologi, filsafat, kebudayaan atau laporan-laporan penelitian nonhukum dan jurnal-jurnal nonhukum sepanjang mempunyai relevansi dengan topik penelitian. Bahan-bahan nonhukum tersebut dimaksudkan untuk memperkaya dan memperluas wawasan peneliti. ${ }^{10}$

${ }^{9}$ Ibid, hal.181

${ }^{10}$ Ibid, hal.183-184 


\subsection{Teknik Pengumpulan dan Pengeloaan Bahan Hukum}

Peneliti mencari peraturan perundang-undangan mengenai atau yang berkaitan dengan isu tersebut. Perundanng-undangan dalam hal ini meliputi baik yang berupa legislation maupun regulation bahkan delegated legislation dan delegated regulation. Selain itu peneliti harus mengumpulakan putusan-putusan pengadilan mengenai isu hukum yang dihadapi. ${ }^{11}$ Selain teknik pungumpulan data tersebut, adapun cara lainnya yaitu dengan melakukan telaah atas isu hukum yang di ajukan. Dalam delik-delik yang dirumuskan secara materiil dan delik-delik yang dikualifisir, penentuan hubungan kausal diperlukan. Selanjutnya dinyatakan bahwa dalam ke dua delik-delik diatas, dimana unsur akibat ditentukan dalam rumusan, maka penentuan elemen kelakuan yang menimbulkan akibat tersebut diadakan dengan menggunakan ajaran tentang hubungan kausal. ${ }^{12}$

\footnotetext{
${ }^{11}$ Ibid, hal.237-238

12 Ibid, hal.245
} 


\section{Hasil Penelitian dan Pembahasan}

\subsection{Putusan Perkara Nomor 04/PDT.G/2007/PN.PSB}

\subsubsection{Posisi Kasus}

Pada hari Minggu tanggal 29 Januari 2006 pukul 12.00 bertempat di sebuah pondok yang berukuran 2 x 2 m di Sasok Rimbo Gadang Durian Sabuik Dusun Kapundung Tanjung Medan, Jorong VI Koto Selatan, Kecamatan Kinali, Kabupaten Pasaman Barat telah terjadi penembakan dimana saat seorang anggota polisi (Briptu Nofrizal, NRP.78101128) Polsek Kinali mendapatkan surat perintah tugas untuk melakukan penyelidikan dan penyidikan atas laporan / pengaduan oleh ibu Ani (warga masyarakat Tanjung Medan Kenagarian Kinali) mengenai tindak pidana kasus pengrusakan sebuah rumah milik Edi warga Jorong Tanjung Medan Pasaman Barat yang diduga dilakukan oleh seorang bernama Sakisman (Akan) dan kawannya Iwan Mulyadi. Surat perintah tugas tersebut tidak hanya ditujukan Briptu Nofrizal saja, namun ditujukan kepada 3 orang anggota yang ke dua diantaranya ialah Brigadir Suardi selaku Kanit Res Kinali dengan Briptu Jimny (bagian dari surat perintah).

Berbekal Surat Perintah Tugas (SPT) Polisi No. Pol SPDIK/01/I/2006/Reskrim tanggal 20 Januari 2006 sekitar pukul 12.00 WIB tersangka (Briptu Nofrizal) bertindak gegabah secara sendiri tanpa berkoordinasi dengan kedua anggota polisi (Brigadir Suardi dan Briptu Jimmy) yang juga di tugaskan dalam Surat Perintah Tugas (SPT) tersebut melakukan penyelidikan terhadap laporan tersebut. Sesampainya di sebuah pondok (gubug) di sawah, tersangka (Briptu Nofrizal melihat Sakisman (Akan) di luar (dibawah) pondok sedangkan korban (Iwan) berada di dalam (diatas) pondok dan menanyakan keberadaan Iwan Mulyadi kepada Sakisman, kemudian Sakisman menjawab bahwa Iwan Mulyadi berada di atas, pada waktu itu juga Briptu Nofrizal 
berteriak dan menyuruh Iwan Mulyadi untuk turun dari pondok, jika tidak maka Briptu Nofrizal akan menembaknya (kesaksian Sakisman).

Kemudian Iwan Mulyadi turun dari pondok, belum sampai dibawah tahu-tahu Briptu Nofrizal menembak Iwan Mulyadi hingga terjatuh ditanah sampai terkulai lemas. Korban terkena tembakan senjata api jenis Revolver Colt 38 Merk Taurus XK 253941 yang mengenai rusuk sebelah kiri dan / atau mengenai syaraf tulang belakang (vertebrata) sehingga menyebabkan korban tidak bisa berdiri dan berjalan alias mengalami kelumpuhan permanent / total berdasarkan Visum Et Revertum Nomor YM. 01. 08. 1. 5. 237 tanggal 30 Januari 2006 yang di tandatangi oleh dr. Edwar Martin, dokter pemerintahan pada Rumah Sakit Umum DR. M. Djamil Padang.

\subsubsection{Dasar Pertimbangan :}

Pasal 1367 KUH Perdata, yang menjelaskan mengenai pertanggung jawaban hukum atas perbuatan melawan hukum yang dilakukan oleh bawahan, sehingga menurut azas ini atasan bertanggungjawab atas segala kerugian yang timbul dari perbuatan melawan hukum yang dilakukan oleh bawahannya.

Dalam kasus ini terdapat 1 (satu) penggugat (pihak Iwan Mulyadi) dan 2 (dua) tergugat, tergugat 1 (Pemerintah Republik Indonesia Cq. Presiden RI di Jakarta, Cq. Kepala Kepolisian Republik Indonesia (Kapolri di Jakarta), Cq. Kepala Kepolisian Daerah Sumatera Barat (Kapolda) di Padang, Cq. Kepala Kepolisian Resor Pasaman Barat (Kapolres Pasaman Barat) di Jln Bhineka Tunggal Ika No. 60 Simpang Empat, Cq. Kepala Kepolisian Sektor Kinali (Kapolsek Kinali) di Kecamatan Kinali Pasaman Barat, tergugat 2 (Briptu Nofrizal). 


\subsubsection{Isi Putusan :}

Akibat kelalaian dalam menjalankan tugasnya tersebut tersangka (Briptu Nofrizal) di jatuhi hukuman berupa hukuman secara kedinasan dari Kapolres Pasaman Barat (penundaan kenaikan pangkat, penundaan mengikuti pendidikan, penempatan di ruangan khusus selama 21 hari), secara hukum publik berdasarkan Putusan Pengadilan Negeri Lubuk Sikaping No. 190/Pid.B/2006/PN.LBS tersangka dijatuhi hukuman penjara selama 18 (delapan belas bulan), hal ini sesuai dengan jawaban tergugat satu (1) atas tuntutan penggugat yang terdapat dalam Putusan Hakim Pengadilan Negeri Pasaman Barat No. 04/PDT.G/2007/PN.PSB yang dalam putusan tersebut tergugat 1 juga dituntut berupa ganti rugi (immateriil) senilai Rp.300.000.000 (tiga ratus juta rupiah) berdasarkan Pasal 1365, 1366, 1367, 1371, KUH Perdata tentang perbuatan melawan hukum yang dilakukan oleh bawahannya yang mengakibatkan kerugian.

\subsection{Alasan atau Dasar Penggugat dalam Mengajukan Gugatan terhadap Polri dalam Perkara Nomor 04/PDT.G/2007/PN.PSB tentang Perbuatan Melawan Hukum.}

Alasan atau Dasar Penggugat dalam Mengajukan Gugatan terhadap Polri dalam Perkara No. 04/PDT.G/2007/PN.PSB tentang Perbuatan Melawan Hukum didasarkan bahwa perbuatan melawan hukum yang dilakukan oleh Polri tersebut mengakibatkan seorang korban mengalami cacat permanen atau kelumpuhan total sehingga menimbulkan dampak besar / penting dan / berupa kerugian materiil maupun immateriil yaitu kelumpuhan permane, kerusakan mental dan fisik, kehilangan pekerjaan / rezeki, kehilangan pendidikan, rusaknya kesehatan mengalami penderitaan, traumatisnyang cukup kuat, kehilangan masa depan. 


\subsection{Analisa Pertimbangan Hukum dalam Putusan Perkara Nomor} 04/PDT.G/2007/ PN.PSB tentang Perbuatan Melawan Hukum yang dilakukan oleh Polri

Analisa Pertimbangan Hukum dalam Putusan Perkara No. 04/PDT.G/2007/ PN.PSB tentang Perbuatan Melawan Hukum yang dilakukan oleh Polri yaitu didasarkan pada unsur-unsur perbuatan melawan hukum antara lain :

\subsubsection{Adanya Suatu Perbuatan}

Perbuatan yang diawali dengan Surat Perintah Tugas dari Tergugat 1 yakni surat No. Pol : Spt/01/1/2006 Sek Kinali untuk melakukan penyelidikan dan penyidikan atas laporan / pengaduan oleh ibu Ani (warga masyarakat Tanjung Medan Kenagarian Kinali) mengenai tindak pidana kasus pengrusakan sebuah rumah milik Edi warga Jorong Tanjung Medan Pasaman Barat yang diduga dilakukan oleh seorang bernama Sakisman (Akan) dan kawannya Iwan Mulyadi. Surat perintah tugas tersebut tidak hanya ditujukan Briptu Nofrizal saja, namun ditujukan kepada 3 orang anggota yang ke dua diantaranya ialah Brigadir Suardi selaku Kanit Res Kinali dengan Briptu Jimny (bagian dari surat perintah).

5.3.2. Perbuatan Tersebut Melawan Hukum (perbuatan yang melanggar hak orang lain yang di jamin oleh hukum)

5.3.2.1. Undang-undang Dasar Negara Republik Indonesia Tahun 1945 Pasal 28 D ayat (1) yang menyatakan "setiap orang berhak atas pengakuan, jaminan, perlindungan dan kepastian hukum yang adil serta perlakuan yang sama didepan hukum".

5.3.2.2. Deklarasi Universal Hak Asasi Manusia tahun 1948 Pasal 5 yang menyatakan bahwa, "tidak seorangpun boleh disiksa atau diperlakukan atau dihukum secara keji, tidak manusiawi atau merendahkan martabat" serta 
Pasal 9 "tidak seorangpun yang dapat ditangkap, ditahan atau diasingkan secara sewenang-wenang”.

5.3.2.3. Ketetapan MPR No.17 Tahun 1998 tentang Hak Asasi Manusia, Pasal 7 yang menyatakan "setiap orang berhak atas pengakuan, jaminan, perlindungan dan kepastian hukum yang adil" dan Pasal 8 "setiap orang berhak mendapatkan perlakuan yang sama didepan hukum".

5.3.2.4. Undang-undang Nomor 39 Tahun 1999 tentang Hak Asasi Manusia, Pasal 58 ayat (1) "setiap anak berhak untuk mendapatkan perlindungan hukum dari segala bentuk fisik atau mental, penelantaran, peralatan buruk dan pelecehan seksual selama dalam pengasuhan orang tua atau walinya, atau pihak lain maupun yang bertanggungjawab atas pengasuhan anak tersebut" serta Pasal 66 ayat (1) "setiap anak berhak untuk tidak dijadikan sasaran penganiayaan, penyiksaan, atau penjatuhan hukuman yang tidak manusiawi”.

5.3.2.5. Undang-undang Nomor 32 Tahun 2004 tentang Perlindungan Anak, Pasal 3 menyatakan "perlindungan anak bertujuan untuk menjamin terpenuhinya hak-hak anak agar dapat tumbuh, berkembang dan berpartisipasi secara optimal sesuai dengan harkat dan martabatkemanusiaan, serta mendapat perlindungan dari kekerasan dsn diskriminasi, demi terwujudnya anak Indonesia yang berkualitas, berakhlak mulia dan sejahtera", Pasal 4 yang menyatakan "setiap anak berhak untuk mendapat hidup, tumbuh, berkembang dan berpartisipasi secara wajar sesuai dengan harkat dan martabat kemanusiaaan, serta dapat perlindungan dari kekerasan diskriminasi" serta Pasal 13 ayat (1) yang menyatakan "setiap anak selama dalam pengasuhan 
orang tua, wali atau pihak lain manapun yang bertanggungjawab atas diskriminasi.

5.3.2.6. Kovenan Hak-Hak Anak, Pasal 16 ayat (1) "tidak seorang anakpun dapat dikenai campur tangan sewenang-wenang atau yang tidak sah atas kehidupan pribadi, keluarga rumah tangga, atau hubungan surat menyuratnya, ataupun diserang secara tidak sah kehormatan dan nama baiknya", dan ayat (2) "anak berhak atas perlindungan hukum terhadap campur tangan atau serangan seperti tersebut diatas", yang telah diratifikasi melalui Keputusan Presiden RI Nomor 36 Tahun 1990 tentang Ratifikasi Konvenan Hak-Hak Anak.

\subsubsection{Adanya Kerugian Bagi Korban}

Kemudian Iwan Mulyadi turun dari pondok, belum sampai dibawah tahu-tahu Briptu Nofrizal menembak Iwan Mulyadi hingga terjatuh ditanah sampai terkulai lemas. Korban terkena tembakan senjata api jenis Revolver Colt 38 Merk Taurus XK 253941 yang mengenai rusuk sebelah kiri dan / atau mengenai syaraf tulang belakang (vertebrata) akibat kelalaiannya tersebut korban tidak bisa berdiri dan berjalan alias mengalami kelumpuhan permanent / total sehingga menimbulkan dampak besar / penting dan / berupa kerugian materiil maupun immateriil yaitu kelumpuhan permanen, kerusakan mental dan fisik, kehilangan pekerjaan / rezeki, kehilangan pendidikan, rusaknya kesehatan mengalami penderitaan, traumatis yang cukup kuat, kehilangan masa depan.

5.3.4. Adanya Kesalahan Dari Pihak Pelaku (adanya unsur kesengajaan)

Kesaksian salah seorang saksi (sakisman) bahwa sesampainya di sebuah pondok (gubug) di sawah, tersangka (Briptu Nofrizal melihat Sakisman (Akan) di luar (dibawah) 
pondok sedangkan korban (Iwan) berada di dalam (diatas) pondok dan menanyakan keberadaan Iwan Mulyadi kepada Sakisman, kemudian Sakisman menjawab bahwa Iwan Mulyadi berada di atas, pada waktu itu juga Briptu Nofrizal berteriak, "turun kamu Iwan Mulyadi kalau tidak saya tembak".

5.3.5. Adanya Hubungan Kausal Antara Perbuatan Dengan Kerugian

Akibat penyelidikan dan penyidikan atas laporan / pengaduan oleh ibu Ani (warga masyarakat Tanjung Medan Kenagarian Kinali) mengenai tindak pidana kasus pengrusakan sebuah rumah milik Edi warga Jorong Tanjung Medan Pasaman Barat yang diduga dilakukan oleh seorang bernama Sakisman (Akan) dan kawannya Iwan Mulyadi tersebut Briptu Nofrizal dengan secara sengaja melakukan penembakan kepada korban (Iwan Mulyadi) sehingga mengakibatkan korban mengalami kelumpuhan total atau cacat permanen dibagian syaraf tulang belakang (vertebrata) dan menimbulkan dampak besar / penting dan / berupa kerugian materiil maupun immateriil yaitu kelumpuhan permane, kerusakan mental dan fisik, kehilangan pekerjaan / rezeki, kehilangan pendidikan, rusaknya kesehatan mengalami penderitaan, traumatisnyang cukup kuat, kehilangan masa depan.

\section{Kesimpulan}

6.1. Dasar atau alasan penggugat dalam mengajukan gugatan terhadap Polri dalam perkara Nomor 04/PDT.G/2007/PN.PSB adalah bahwa perbuatan melawan hukum yang dilakukan oleh Polri mengakibatkan korban (penggugat) tidak bisa berdiri dan berjalan alias mengalami kelumpuhan permanent total sehingga menimbulkan dampak besar penting dan berupa kerugian materiil maupun immateriil yaitu kelumpuhan permanen, kerusakan mental dan fisik, kehilangan pekerjaan rezeki, kehilangan 
pendidikan, rusaknya kesehatan mengalami penderitaan, traumatis yang cukup kuat, kehilangan masa depan.

6.2. Dasar pertimbangan hukum dalam putusan perkara Nomor 04/PDT.G/2007/ PN.PSB tentang perbuatan melawan hukum yang dilakukan oleh Polri didasarkan pada unsur perbuatan melawan hukum yaitu : adanya suatu perbuatan, perbuatan tersebut melawan hukum (perbuatan yang melanggar hak orang lain yang dijamin oleh hukum), adanya kesalahan dari pihak pelaku (adanya unsur kesengajaan), adanya kerugian bagi korban, adanya hubungan kausal antara perbuatan dengan kerugian. 


\section{DAFTAR PUSTAKA}

\section{Literatur Ilmiah}

Ali, Zainuddin, Metode Penelitian Hukum, Jakarta : Sinar Grafika, 2009.

Anwar, Yesmil dan Adang, Sistem Peradilan Pidana ( Konsep, Komponen dan Pelaksanaannya dalam Penegakan Hukum di Indonesia, Bandung : Widya Padjajaran, 2009

Costanzo, Mark, Aplikasi Psikologi Dalam Sistem Hukum, Yogykarta :Pustaka Pelajar, 2000.

Farid, Zainal Abidin, Hukum Pidana 1, Jakarta : Sinar Grafika, 2010

Friedman, Lewrence M, Sistem Hukum Perspektif Ilmu Sosial, Bandung : Nusa Media, 2010.

Fuady, Munir, Perbuatan Melawan Hukum Pendekatan Kontemporer, Bandung : PT. Citra Aditya, 2001

Islamy dan M.Irfan, Prinsip-Prinsip Perumusan Kebijaksanaan Negara,

Konsep Hukum Perdata, Jakarta : PT. Raja Grafindo Persada, Jakarta : Bumi aksara.

Kamus Besar Bahasa Indonesia.

Kelana, Momo Memahami Undang-Undang Kepolisian Republik Indonesia, Jakarta : Sinar Grafika.

Khoidin, M dan Sadjijono, Menatap Wajah Polisi Kita, Yogyakarta : LaksBang Pressindo.

Lamintang, P.A.F, dan Theo Lamintang, Delik-Delik Khusus, Kejahatan Terhadap Nyawa, Tubuh, dan Kesehatan, Jakarta : Sinar Grafika, 2010.

Manan, Abdul, Etika Hakim dalam Penyelenggaraan Peradilan Suatu Kajian dalam Sistem Peradilan Islam, Jakarta, Prenada media Group : 2007.

Marzuki, Peter Mahmud, Penelitian Hukum, Jakarta : Kencana Prenada Media Group, 2016.

Merpaung, Leden, Proses Penanganan Perkara Pidana, Jakarta : Sinar Grafika, 1992.

Moeljatno, Asas-Asas Hukum Pidana, Jakarta : Rineka Cipta, 2002.

Pedoman Pelaksanaan Tugas dan Administrasi Pengadilan, Buku II, April 1994, Jakarta : MA RI.

Rahardi, Pudi, Hukum Kepolisian, Surabaya : Laksbang Mediatama, 2007.

Sadjijono, Etika Profesi Kepolisian, Suatu Telaah Filosofis, Konsep dan Implementasinya dalam Pelaksanaan Tugas, Surabaya : Alfina, , 2006.

Sahetapy, Agustinus dan Pohan, Hukum Pidana, PT. Citra Aditya Bakti : Bakti, 2007.

Sisworo, Soejono Koesoemo, Tinjauan Sepintas Beberapa Aliran Filsafat Hukum falam relasi dan relevannya dengan pembinaan hukum Indonesia, 1988. 
Soepomo, Hukum Acara Perdata Pengadilan Negeri, Jakarta : Pradnya Paramita, 1993.

Soerodibroto, Soenarto, KUHP dan KUHAP Dilengkapi Yurisprudensi Mahkamah Agung dan Hoge Raad, Jakarta : PT RajaGrafindo Persada, 2014.

Soesilo, KUHP dan KUHAP, Yogyakarta : Gama Press, 2008.

Subekti, Hukum Pembuktian, Jakarta : Pradnya Paramita, 1987. dan R.Tjitrosudibio, Kitab Undang-Undang Hukum Perdata, Jakarta : PT Pradnya Paramita 2009.

Sunarso, Siswanto, Filsafat Hukum Pidana Konsep, Dimensi, Dan Aplikasi, Jakarta : PT Raja Grafindo Persada, 2015.

Supriadi, Etika \& Tanggung Jawab Profesi Hukum Di Indonesia, Jakarta : Sinar Grafika, 2006.

Suseno, Frans Magnis, Etika Abad ke-20, Yogyakarta : Kanisius, 2006

Tadjosaputro, Liliana, Etika Profesi dan Profesi Hukum, Semarang : Aneka Ilmu, 2006.

Tirtaamidjaja, , Kedudukan Hakim dan Jaksa, Jakarta : Djambatan, 1962.

Wardaningsih, Hukum Dan Peradilan, Jakarta : CV.Pamularsih, 2009.

\section{Perundang-undangan}

Kitab Undang-Undang Hukum Pidana (KUHP).

Kitab Undang-Undang Hukum Perdata (KUH Perdata).

Putusan Hakim Pengadilan Negeri Pasaman Barat No.04/PDT.G/2007/PN.PSB Tahun 2008.

Undang-Undang No.8 Tahun 1948 tentang Senjata Api.

Undang-Undang No.12 Tahun 1951 tentang Mengubah "Ordonnantietijdelijke Bijzondere Strafbepalingen" (STBL. 1948 NOMOR 17) Dan Undang-Undang Republik Indonesia Dahulu Nomor 8 Tahun 1948.

Ordonansi Senjata Api tahun 1939 jo UU Darurat No.12 Tahun 1951.

Undang-Undang No. 2 Tahun 2002 tentang Pengertian Fungsi dan Tujuan Kepolisian RI.

PP No. 2 Tahun 2003 tentang Kewajiban, Larangan dan Sanksi bagi Anggota Polri.

Peraturan Kapolri No. 7 Tahun 2006 tentang Kode Etik Profesi Polri.

Peraturan Kapolri No. 8 Tahun 2006 tentang Organisasi dan Tata Kerja Komisi Kode Etik Polri.

Peraturan Kepala Kepolisian Negara Republik Indonesia No. 1 Tahun 2009 tentang Penggunaan Kekuatan.

Peraturan Kepala Kepolisian Negara Republik Indonesia No. 8 Tahun 2009 tentang prosedur tembak ditempat. 